\title{
Reproduction and Population Growth in Free-Ranging Mantled Howling Monkeys
}

\author{
KENNETH E. GLANDER \\ Department of Anthropology, Duke University, Duram, North Carolina 27706
}

\begin{abstract}
KEY WORDS Alouatta palliata, Reproduction, Demography, Infant survival
\end{abstract}

\begin{abstract}
Free-ranging mantled howling monkey (Alouatta palliata Gray) females experienced a regular estrus cycle averaging 16.3 days, demonstrated sexual skin changes, and participated in multiple matings before becoming pregnant. Gestation averaged 186 days. The average interval between births was 22.5 months. Sexual maturity occurred at approximately 36 and 42 months for females and males, respectively. Female age at first birth was about $3 \frac{112}{2}$ years. Births were scattered during some years and clustered during others. The age, rank, and parity of the females affected infant survival. More female than male infants survived to one year of age. Increased population size was the result of immigration rather than births.
\end{abstract}

Until now, relatively little information has been available on the reproductive parameters or physical development of mantled howling monkeys (Alouatta palliata, Gray). Developmental stages based on size and changes in behavior were presented by Carpenter ('34), and Altmann ('59) described the behavioral ontogeny of an infant during 32 days of study. Almost all available information on howler reproduction comes from Carpenter's ('34) eight month study of free-ranging monkeys and Wislocki's ('30) work on collected specimens. Both Carpenter and Wislocki concluded that howlers were sexually active year round and lacked a birth season. Carpenter ('34) found howler females to be sexually receptive for two to three days at a time, but to show no sexual skin changes. He also reported multiple matings before pregnancy. Napier and Napier ('67) listed the gestation length for howlers as unknown, whereas Dukelow ('70) and Walker ('75) reported the gestation length to be about 139 and 140 days, respectively. Carpenter ('65) estimated the age of reproductive maturity for howlers to be four to five years for females and six to eight years for males. The only published report on captive howler reproduction briefly describes the birth of an $A$. caraya infant (Shoemaker, '78).

My observations on one group of mantled howling monkeys since September 6, 1970, provide records of sufficient continuity that I can estimate the length of the estrus cycle, length of gestation, female ages at first birth, and length of interbirth intervals. Additional information gathered during the study includes the documentation of sexual skin changes; infant sex ratio at birth; the effect of the mother's age, rank, and parity on her infant's survival; and population growth rates. My data in these areas are by no means complete, but they provide new information in some cases and warrant rethinking of established ideas on howler reproduction in other instances.

\section{METHODS}

The data reported here were collected as part of a continuing long-term investigation of the behavior and ecology of one group of mantled howling monkeys located at Hacienda La Pacifica, a cattle ranch $5 \mathrm{~km}$ northwest of Cañas, Guanacaste Province, Costa Rica. The same group has been studied since 1970. Table 1 lists the periods of observation and the group composition on the first day of each observation period. Changes in composition occurred due to birth, death, emigration, and immigration. The study site, climate, and feeding behavior have been described in detail elsewhere (Glander, '75; '78; '79).

Received January 22, 1979; accepted September 26, 1979. 
TABLE 1. Observation periods and the group composition on the first day of each period

\begin{tabular}{|c|c|c|c|c|c|c|}
\hline \multirow{2}{*}{ Dates of studies } & \multirow{2}{*}{$\mathrm{m}$} & \multicolumn{2}{|c|}{$\begin{array}{l}\text { Group } \\
\text { composition }\end{array}$} & \multirow[b]{2}{*}{$\mathrm{i}$} & \multirow{2}{*}{$\begin{array}{l}\text { Observation } \\
\text { frequency }\end{array}$} & \multirow{2}{*}{ Observers } \\
\hline & & $\mathbf{f}$ & $\mathbf{j}$ & & & \\
\hline Sept. 3-26 1970 & 2 & 8 & 2 & 0 & Daily & K.E. Glander \\
\hline June 231972 - Aug. 261973 & 2 & 5 & 4 & 2 & Almost daily & K.E. \& M.H. Glander \\
\hline June $23-301974$ & 4 & 7 & 2 & 1 & Daily & K.E. Glander \\
\hline Jan. 1, Feb. 3, 14, \& 241975 & 4 & 7 & 2 & 4 & Census & N.J. Scott, Jr. \\
\hline Aug. 4-10 1975 & 3 & 7 & 7 & 1 & Daily & K.E. \& M.H. Glander \\
\hline Dec. 25 - Jan. 91976 & 3 & 7 & 6 & 0 & Daily & K.E. Glander \\
\hline July 4-19 1976 & 3 & 10 & 4 & 1 & Daily & K.E. Glander \\
\hline Mar. 2- May 11977 & 3 & 9 & 3 & 7 & Daily & $\begin{array}{l}\text { K.E. Glander ( } 2 \text { weeks) } \\
\text { M.A. Gottenborg }\end{array}$ \\
\hline Nov, 14-20 1977 & 3 & 8 & 8 & 1 & Daily & K.E. Glander \\
\hline May 7-18 1978 & 3 & 9 & 6 & 1 & Daily & $\begin{array}{l}\text { K.E. Glander } \\
\text { M. Clarke }\end{array}$ \\
\hline Nov. 121978 & 3 & 8 & 4 & 3 & Almost daily & $\begin{array}{l}\text { K.E. Glander ( } 1 \text { week) } \\
\text { M. Clarke ( } 18 \text { month } \\
\text { study begun) }\end{array}$ \\
\hline
\end{tabular}

$m=$ male; $f=$ female $; j=$ juvenile $; i=$ infant.

The exact ages of the original 1970 group are unknown, but at the beginning of the 1972 observation period, all adult animals were captured and age estimates were made based on tooth wear. Estimates of infant and juvenile ages in 1972 were based on behavior and body size (Carpenter, '34). These estimates have been adjusted as data on animals of known age accumulate. Table 2 lists physical and behavioral characteristics for animals of known age. The oldest animals of known birthdate are now more than seven years old.

Since 1973 (except for 1974) the animals have been captured once a year for weighing, measuring, and marking (see Scott et al., '76, for capture methods). A thorough physical exam, including palpation, is given each animal. Each group member can be recognized by colored leg bands for adult males, colored neck collars for adult females, and tattoes for infants and juveniles.

I have never observed a birth, but in 1973, I saw infants that were still wet and, therefore, presumed to be less than two hours old. The criteria in Table 2 have been used to estimate the age (and thereby establish the month of birth) of all infants born since 1973, except for one birth each in 1978 and 1979, recorded by Margaret Clarke.

The condition of the sexual skin of each adult female was recorded almost every day during the 14 month study. Changes consisted of a cyclic pattern of swelling with exposure of the labia minor at peak swelling and associated color change from white to light pink. The tumidity of the vulva and perianal region was scored minus (-), no swelling (Fig. 1A); plus $(+)$, slight swelling; or double-plus $(++)$, fullswelling (Fig. 1B).

Gestation length was determined by counting the number of days from birth back to the last observed double-plus swelling. Since copulations only occurred during these swellings, conception was assumed to have occurred at that time. During pregnancy, a female's sexual skin did not undergo change. Any female demonstrating no change in her sexual skin for two months was assumed to be pregnant.

The social rank of each animal was determined from dyadic interactions ordered in a matrix. The interactions involved disputed feeding, resting, and sleeping places. An animal was dropped in rank whenever a reversal occurred, i.e., was supplanted by an animal formerly ranked lower.

The terms primiparous, and multiparous are used. Primiparous refers to females having produced one infant, and multiparous refers to females having produced more than one infant.

The data on sex ratio and seasonal birth distribution were analyzed using chi-square goodness of fit tests. The Fisher exact test was used to analyze infant mortality.

\section{RESULTS \\ Birth}

There were physiological and behavioral indicators that birth was imminent. Approximately three or four days before parturition, the female's perineal area underwent "break- 
TABLE 2. Known ages and characteristics of La Pacifica mantled howling monkeys

\begin{tabular}{|c|c|c|c|}
\hline Class & Physical characteristics & $\begin{array}{l}\text { Weight } \\
\text { grams }\end{array}$ & Age \\
\hline Infant- 1 & Hair silver-gray. Carried ventrally by mother. & $275-400$ & 2 days or less \\
\hline Infant-2 & Hair light brown. Carried ventrally by mother. & & $2-21$ days \\
\hline Infant-3 & $\begin{array}{l}\text { Hair light brown to brownish-black. Carried dorsally by } \\
\text { mother. The change from the natal coat color to the } \\
\text { adult coat color is complete by the } 12 \text { th week. }\end{array}$ & . & $21-90$ days \\
\hline Juvenile-1 & $\begin{array}{l}\text { Adult pelage, brownish-black to black. Carried dorsally } \\
\text { by mother only during difficult crossings. }\end{array}$ & & $3-6$ months \\
\hline Juvenile-2 & $\begin{array}{l}\text { Adult pelage. Not carried at all by mother. Males } \\
\text { scrotum remains black and nonpendulous. Testes } \\
\text { not in scrotum. }\end{array}$ & $1,500-3,500$ & $6-30$ months \\
\hline Subadult female & $\begin{array}{l}\text { Development of mantle. Sexually mature by } 36 \\
\text { months. First infant about } 43 \text { months. }\end{array}$ & & $30-48$ months \\
\hline Subadult male & $\begin{array}{l}\text { Development of secondary sex characteristics: beard, } \\
\text { mantle, enlargement of head, scrotum becomes } \\
\text { pendulous, and changes from black to } \\
\text { white with many black spots. Testes in } \\
\text { scrotum. Begin to produce loud call. }\end{array}$ & & $30-48$ months \\
\hline Adult female & Full size reached. & $4,000-6,000$ & $48+$ months \\
\hline Adult male & $\begin{array}{l}\text { Secondary sex characteristics fully developed. } \\
\text { Scrotum fully pendulous and white with a } \\
\text { few black spots. }\end{array}$ & $5,000-7,000$ & $48+$ months \\
\hline
\end{tabular}

down" similar to that experienced by bovids. It is called breakdown in cattle because the perineal and surrounding area becomes loose and elastic in preparation for the passage of the infant (pers. obs.).

Behaviorally, the mother-to-be became much less aggressive just prior (varied with the individual, but about 1 week) to the birth of an infant. She was easily supplanted. Even the top ranked female (Whitered) was easily supplanted by all other females and dropped to the bottom of the ranking just prior to her infant's birth and remained there for about one month after parturition. As her infant matured, she reasserted herself and gradually moved back up the hierarchy, but was unable to regain her former position. Unlike other females, primiparous females continued to engage in dominance interactions after the birth of their first infant. With the advent of their second infants, all females demonstrated their reluctance to enter into dominance interactions or, if forced into the interaction, were easily supplanted.

All mothers paid particular attention to their newborn, picking them up by their tails and licking their navels and perianal regions (pos- sibly to stimulate voiding). Whitered was observed to chew her infant's umbilical cord. Both Greenred and Whitered ingested fecal matter from their newborn. For three weeks after birth, the infants rode in the ventral position. Thereafter, they rode dorsally until they were three months old. At that age their mothers began to force them to move on their own.

\section{Interbirth intervals}

The amount of time between a female's successive births consisted of a period of postpartum acyclicity, a sexual receptive phase, and gestation. Estimates of each of these are presented below.

\section{Postpartum acyclicity}

A female did not accept or solicit sexual advances for three to four months following the birth of her infant. If the infant died within this time, the period of acyclicity ended abruptly. Only two infants died within this time period during the study. In both cases, the females began to solicit mating within three weeks of their infant's death. Both became pregnant almost immediately, giving birth 9 and 10 months after the birth of their previous infants. 

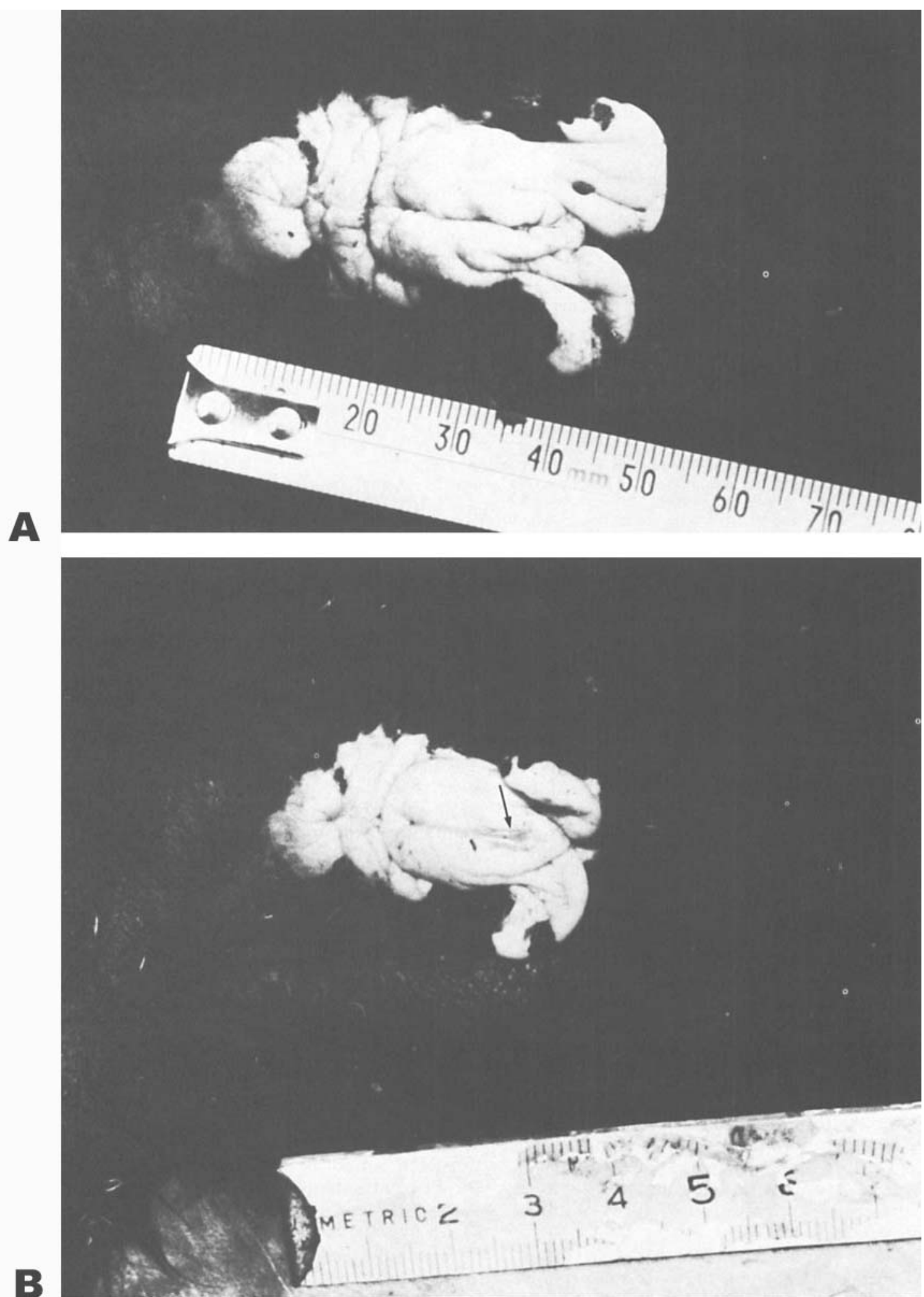

Fig. 1. Greedred's vulva. The tumescent vulva (B) has an engorged appearance with the bright pink labia minor exposed (arrow). In the flaccid condition (A), no labia minor exposure exists and the vulva appears uniformly white in color. 


\section{Sexual receptivity}

Adult females accepted or solicited sexual advances from males only during certain times. The number of days between these receptive times varied within and between females from 11 to 24 days, with a mean of 16 days (Table 3 ). The interval between sexual receptivity was calculated from the midpoint of one maximal vulvar swelling to the next.

The length of the interval spent cycling before primiparous and multiparous females became pregnant varied from 8 to 15 months (mean 12.8, $\mathrm{n}=16$ ). All of the females experienced multiple matings without becoming pregnant. I assumed that ovulation was not occurring during any of those matings. For example, Blue was observed to mate at least once during seven consecutive estrus cycles while Greenred was observed to copulate at least once during ten consecutive estrus cycles. In fact, each of these females mated two and three times during many of these cycles, but neither became pregnant.

Adult females were receptive to copulations for two to four days during each cycle. However, the two adult males reacted quite differently to estrous females. Their reactions were predictable based on their respective ranks. The alpha male (Baker) frequently rejected a female's invitation to copulate one day and then followed her closely and copulated with her several times the next day. The beta male (Scar) took advantage of all opportunities to copulate and many times was observed to copulate with a female who had just been rejected by Baker. However, Baker never permitted Scar to approach or copulate with females in the middle of their receptive periods. Scar was not prevented from copulating with females either before or after the midpoint.

The adult males routinely checked the urine of each female, sometimes moving from one tree into another to sniff the spot where urine had fallen. I was able to distinguish between urine from receptive and nonreceptive females by the pungent odor of the former. Males sampled urine directly by placing their noses and mouths into the urine flow and then raised their head with lips slightly parted, a behavior resembling flehmen in ungulates and cats (Leuthold, '77).

The howlers performed a stereotyped behavior which came to be known as the "greeting ceremony." Participants were always the same sex. Males older than two years did not engage in this behavior with animals of their own age or older. However, all males older than two were observed to participate in greeting ceremonies with males less than two years old. Greeting ceremonies occurred throughout the year. Among females, they were highest in frequency during cycling. The ceremony for females consisted of animals approaching one another, sniffing each other's axillary region (location of the nipples), and then sniffing and/or licking each other's genitalia. Small amounts of urine were often expelled during the licking or sniffing. Partial sequences of the above also occurred. No urine was expelled if the participants were males.

One case of postconception mating was observed. On June 16, 1973, Greenred solicited and copulated once with Scar. Later the same day, she again solicited both males; they ignored her and no further copulations were seen. She was 17 weeks pregnant at the time of the copulation, since she gave birth on August 5, 1973.

\section{Gestation}

Gestation length for four females ranged from 180 to 194 days. The mean gestation length was 186 days ( $\mathrm{SD}=6$ days).

TABLE 3. Estrus cycle length

\begin{tabular}{|c|c|c|c|c|c|c|}
\hline \multirow[b]{2}{*}{ Individual } & & \multicolumn{5}{|c|}{ Estrus cycle } \\
\hline & & Mean & $\begin{array}{l}\text { Std error } \\
\text { of mean }\end{array}$ & Std dev & Range & $\mathrm{N}$ \\
\hline Whitered & & 14.0 & 1.3 & 2.8 & $12-19$ & 5 \\
\hline Blue & & 18.4 & 1.4 & 3.8 & $14-24$ & 7 \\
\hline Yellow & & 14.8 & 0.6 & 1.3 & $13-16$ & 4 \\
\hline Greenred & & 18.4 & 1.2 & 2.6 & $16-22$ & 5 \\
\hline Dogcollar & & 14.0 & - & - & - & 1 \\
\hline Green & & 11.0 & - & - & - & 1 \\
\hline & Group & 16.3 & 0.7 & 3.5 & $11-24$ & 23 \\
\hline
\end{tabular}


Interval between successive births

Based on the above data, the expected interval between births should be 21 to 23 months. The actual mean time for 16 complete interbirth intervals was 22.5 months (Table 4).

\section{Birth season}

The distribution of births during the past seven years does not appear to fit any particular pattern. Some births occurred during almost all months and the seasonal distribution was not significantly different $\mathrm{X}^{2}{ }_{1}=0.81$, $\mathrm{P}>0.05)$. However, there were scattered (spread over 6 or more months) births during some years-1973 and 1978-and concentrated ( $80 \%$ of the births distributed over 3 months or less) births during other years-1975 and 1977 (Fig. 2). If infant survival to one year of age is added to Figure 2, a relationship between infant survival and concentration of births is suggested. The mortality rate for scattered births ranged from 50 to 100 percent (1972, 1973,1974 , and 1976), compared to a mortality rate of 15 to 25 percent for concentrated births (1975 and 1977). Births occurring outside the months of concentration also suffered 50 percent mortality, i.e., the infant born in July, 1975, died while the one born in September, 1977 , survived to one year of age. Both of these infants were born to the same female, the $\mathbf{1 9 7 5}$ infant was her first.

Survival information is incomplete for the 1978 infants, since they are not yet one year old. However, two of the five have already died. Since the 1978 infants were scattered, their survival rate is expected to be less than 50 percent.

Apparently, not all howler groups in the same area are on the same birth schedule. Jones ('78), working with the group inhabiting the forest that was upriver and contiguous with the forest inhabited by my study group, reported five births in February, 1976, one in May, one in June, one in August, and two in
September of that year. The seasonal distribution for these births was not significantly different (Jones, '78). For my group, 1976 was an off year, with only one female producing an infant. Depending then on which group and when a group was studied, the observer could receive very different impressions of birth patterns unless the study was long-term.

\section{Sex ratio at birth}

Since 1971, 31 births have been recorded; 15 males, 9 females, and 7 unknown. This distribution is not significantly different from a $50: 50$ sex ratio $\left(X_{1}^{2}=1.50, P>0.05\right)$. An attempt was made to sex infants within the first two months of their lives. Positive verification of the 24 sexed infants was made either when they were captured or from the body of dead infants. Eight of $15(53 \%)$ infant males have survived to one year of age. Comparatively, nine of nine (100\%) females have survived to one year of age. This mortality difference between males and females is significant $(\mathrm{P}=0.019$, Fisher exact test $)$.

\section{Infant mortality and the mother's age, rank, and parity}

For mantled howlers, age, social rank, and parity are closely linked and all affect infant mortality. Age and social rank are inversely correlated (Jones, '78). I found a similar relationship in my group; the younger the adult female the higher the rank. The young adult females reached the alpha position just before or just after producing their first infant. No infant of a $3^{\frac{1}{2}}$ to 4 year old primiparous female (the age at first birth) has survived (Table 5). Comparatively, infant mortality for multiparous females five or more years old was 27 percent. These differences are significant $(\mathrm{P}=0.014$, Fisher exact test $)$.

Social rank also affected infant mortality. Alpha females lost 100 percent of their infants compared to an average 28 percent mortality

TABLE 4. Interbirth intervals

\begin{tabular}{lccccc}
\hline Individual & $\begin{array}{c}\text { Mean } \\
\text { months }\end{array}$ & $\begin{array}{c}\text { Std error } \\
\text { of mean }\end{array}$ & Std dev & Range & $\mathrm{N}$ \\
\hline Whitered & 22.0 & 2.0 & 3.5 & $18-24$ & 3 \\
Yellow & 22.3 & 0.7 & 1.2 & $21-23$ & 4 \\
Dogcollar & 22.0 & 1.0 & 1.7 & $22-23$ & 4 \\
Green & 23.5 & 0.4 & 0.7 & $23-24$ & 2 \\
Bonnie & 25.0 & - & - & - & 1 \\
Blue & 22.0 & - & - & - & 1 \\
Purple & 21.0 & - & 2.0 & $18-25$ & 16 \\
& & & 0.6 & & - \\
\hline
\end{tabular}




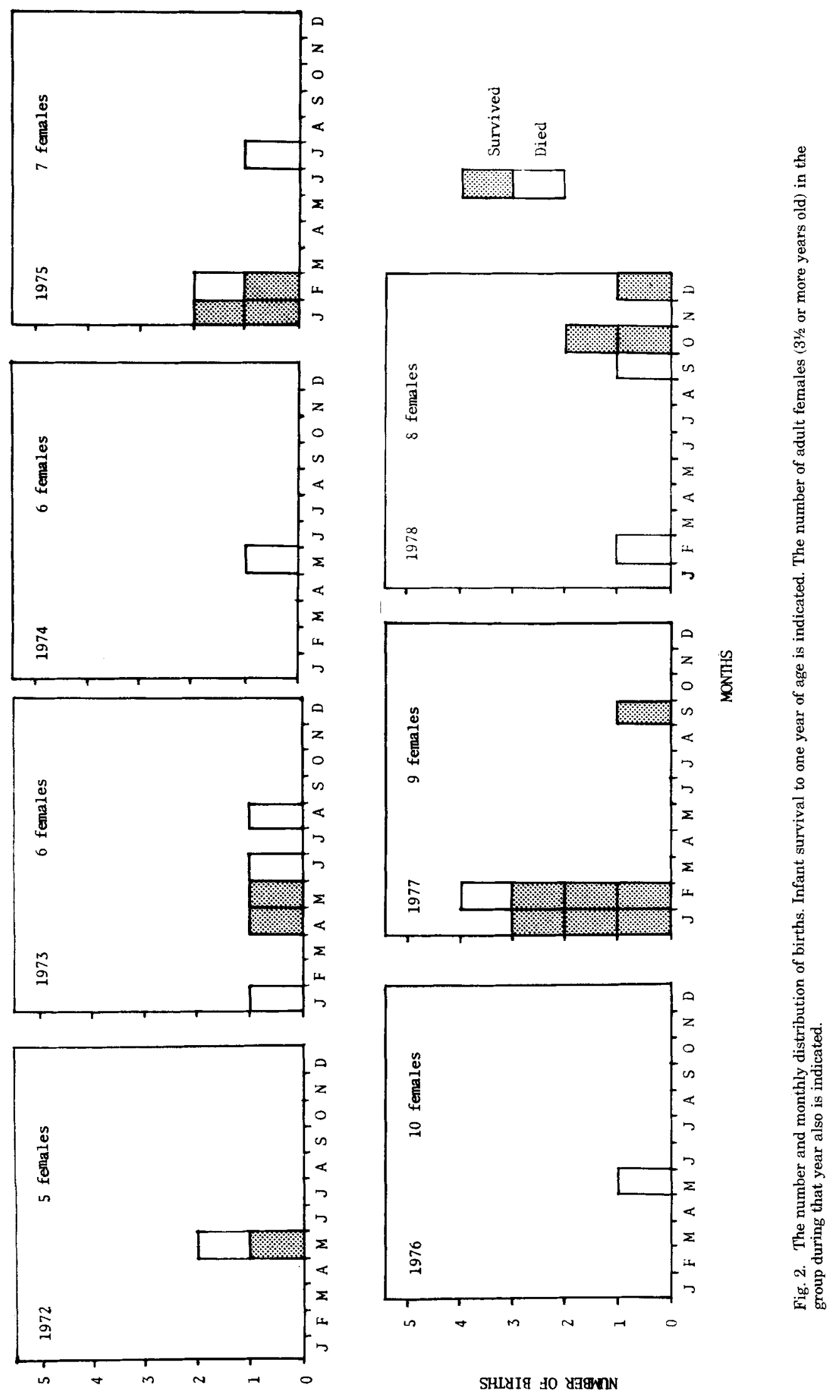


TABLE 5. Number of infant loss as a function of age, parity, and social rank of the mother

\begin{tabular}{|c|c|c|c|c|}
\hline & \multicolumn{4}{|c|}{ Reproductive outcome } \\
\hline & \multirow[b]{2}{*}{$\mathbf{N}$} & \multicolumn{2}{|c|}{ Mortality within } & \multirow{2}{*}{$\begin{array}{l}\text { Percent } \\
\text { mortality }\end{array}$} \\
\hline & & 4 months & 12 months & \\
\hline \multicolumn{5}{|l|}{ Age (years) and parity } \\
\hline $3^{1 / 2}$ to 5, primiparous & 4 & 4 & 0 & 100 \\
\hline $5+$, multiparous & 22 & 2 & 4 & 27 \\
\hline \multicolumn{5}{|l|}{ Rank } \\
\hline 1 & 3 & 3 & 0 & 100 \\
\hline 2 & 5 & 0 & 1 & 20 \\
\hline 3 & 3 & 0 & 1 & 33 \\
\hline 4 & 3 & 0 & 1 & 33 \\
\hline 5 & 4 & 0 & 1 & 25 \\
\hline 6 & 5 & 0 & 3 & 60 \\
\hline 7 & 1 & 0 & 0 & 0 \\
\hline 8 & 1 & 0 & 0 & 0 \\
\hline 9 & 1 & 0 & 0 & 0. \\
\hline
\end{tabular}

Infants not yet one year of age are not included.

for ranks two through five (Table 5). The sixth ranked female suffered 60 percent infant mortality. The sample size of one each is too small to say anything about ranks seven, eight, and nine, and most of the births occurred when the group contained only six females (Table 5 ). It is apparent that the highest and lowest ranked females (considering only six ranks) are at a reproductive disadvantage $(\mathrm{P}=0.033$, Fisher exact test).

Tenure in rank for the female alpha position averaged 12.5 months with a range of 3 to 36 months $(n=6)$. Given the 23 month interbirth interval, no female is likely to have more than her first infant while occupying the alpha position. In fact, none of the females had more than one infant while alpha. Tenure for all other positions was directly related to the duration of rank occupancy for the alpha position, since all females moved down one rank when a new animal became alpha.

\section{Sexual maturity and age at first birth}

Bonnie, a young female born in the group, experienced her first estrus when she was 34 months old. She gave birth to her first infant in March, 1975, when she was 43 months old. A six month gestation meant that she conceived in September, 1974, or when she was 37 months old.

Male mantled howlers less than two years old did not have pendulous scrotums and their testicles remained in the abdomen or inguinal canal (palpated). The testicles descended and the scrotum became pendulous by the time they were 36 months old. Sexual activity may be physiologically possible at that time, but probably does not occur until some months later because of social effects. Able, an offspring of Whitered, was observed to copulate several times when he was 52 months. Macho, a young male (estimated 42 to 48 months old) joined the study group between March and November, 1977. In May, 1978, he was observed to copulate with several females.

\section{Fecundity and postreproduction}

The oldest female in my group is now estimated to be at least 16 years old. Currently, the group also contains females estimated to be 13 , 14, and 15 years old. All continue to produce offspring every two years. Continued study should provide more information about these reproductive phenomena that are often invoked in kin selection theory.

\section{Age distribution}

Table 6 shows the fluctuation in the age composition of the group for a seven year period. The four age ranges were chosen because: 1) Mortality is highest during the first year $(38 \%)$; 2) most of the emigrating and immigrating animals are between one and four years old (the mortality rate for this age range is unknown since most of them left the group); 3 ) four to 15 years represents a time of active group membership with low mortality (3\%); 4) the upper limit of 15 years is an arbitrary figure for old age and may be too low, since some of the females are now estimated to be 16 years old and still reproducing; one male is estimated to be 21 years old. A howler group in 
TABLE 6. Male and female age distribution

\begin{tabular}{|c|c|c|c|c|c|c|c|c|c|c|}
\hline \multirow[b]{2}{*}{ Year } & \multicolumn{3}{|c|}{$0-1$ year } & \multicolumn{2}{|c|}{$1-4$} & \multicolumn{2}{|c|}{$4-15$} & \multicolumn{2}{|c|}{$15+$} & \multirow[b]{2}{*}{$\mathbf{N}$} \\
\hline & $\mathrm{m}$ & $f$ & $*$ & $\mathrm{~m}$ & $f$ & $\mathrm{~m}$ & $\mathbf{f}$ & $\mathrm{m}$ & $\mathrm{f}$ & \\
\hline 1972 & 1 & 0 & 1 & 2 & 2 & 1 & 5 & 1 & 0 & 13 \\
\hline 1973 & 2 & 2 & 1 & 3 & 1 & 1 & 6 & 1 & 0 & 17 \\
\hline 1974 & 1 & 0 & & 2 & 3 & 1 & 6 & 1 & 0 & 14 \\
\hline 1975 & 3 & 2 & & 0 & 3 & 2 & 7 & 1 & 0 & 18 \\
\hline 1976 & 0 & 0 & 1 & 1 & 6 & 2 & 7 & 1 & 0 & 18 \\
\hline 1977 & 2 & 3 & 2 & 1 & 3 & 1 & 7 & 1 & 0 & 20 \\
\hline 1978 & 1 & 1 & 2 & 2 & 3 & 1 & 6 & 2 & 1 & 19 \\
\hline Mean & & & & & & & & & & 17 \\
\hline
\end{tabular}

$\mathbf{m}=$ male; $\mathbf{f}=$ female; $^{*}=$ sex unknown.

TABLE 7. The individual birth, death, immigration, and emigration rates

\begin{tabular}{|c|c|c|c|c|c|c|c|}
\hline Year & & $\begin{array}{c}\text { Birth } \\
\text { rate } \\
b_{0}\end{array}$ & $\begin{array}{c}\text { Death } \\
\text { rate } \\
\mathrm{d}_{0}\end{array}$ & $\mathrm{~b}_{0}-\mathrm{d}_{0}$ & $\begin{array}{c}\text { Immig } \\
\text { rate } \\
\mathrm{I}_{0}\end{array}$ & $\begin{array}{c}\text { Emig } \\
\text { rate } \\
\mathbf{E}_{\circ}\end{array}$ & $\mathrm{I}_{0 j}-\mathrm{E}_{o}$ \\
\hline 1972 & & 0.15 & 0 & 0.15 & 0 & 0 & 0 \\
\hline 1973 & & 0.29 & 0.24 & 0.05 & 0 & 0 & 0 \\
\hline 1974 & & 0.07 & 0.07 & 0 & 0 & 0.07 & -0.07 \\
\hline 1975 & & 0.28 & 0 & 0.28 & 0.06 & 0.06 & 0 \\
\hline 1976 & & 0.06 & 0.17 & -0.11 & 0.06 & 0 & 0.06 \\
\hline 1977 & & 0.40 & 0.20 & 0.20 & 0.05 & 0.05 & 0 \\
\hline \multirow[t]{2}{*}{1978} & & 0.26 & 0.16 & 0.10 & 0.05 & 0.16 & -0.11 \\
\hline & Mean & 0.22 & 0.12 & 0.10 & 0.03 & 0.05 & -0.02 \\
\hline
\end{tabular}

this area might be expected to have the following age distribution: 21 percent under one year of age, 27 percent between 1 and 4 years, 45 percent between 4 and 15 years, and 8 percent over 15 years old (Table 6).

\section{Population growth}

The intrinsic rate of increase ( $r$ ) for the study group was positive for six of the seven years with only 1976 showing a negative " $r$ " (Table 7). The average " $r$ " was 0.10 . However, " $r$ ", which is equal to birth rate $\left(b_{0}\right)$ minus death rate $\left(\mathrm{d}_{\mathrm{o}}\right)$ (Wilson and Bossert, '71), does not adequately describe the growth of this population, since immigration and emigration are occurring.

Only 10 of the infants ( 6 females and 4 males) have survived to two years of age and only four of those have remained in the group, those being Bonnie, Orange, and Tala (females) and Able (male). Orange died in 1976 when she was 40 months old and Able died in 1977, when he was 70 months old. Bonnie is seven years old and presently the third ranked female. Tala is 30 months old and shows no signs of leaving the group. The other six left the group between their second and fourth year. I know that some of them are still alive since three of them (1 female and 2 males) have been seen solitary during 1979 , and other solitary juvenile males and females have been sighted during the past seven years. Additionally, five animals (4 females and 1 male) from other groups have joined the study group during the same time (Glander, in prep.). None of the five immigrants had earlier emigrated from the study group. The two year olds in my group were ear notched or tattooed; the animals joining were unmarked when captured. This indicates that juveniles from other groups also leave their maternal groups and survive.

Given the above, the addition of immigration $\left(\mathrm{I}_{0}\right)$ and emigration $\left(\mathrm{E}_{0}\right)$ rates are necessary to characterize the growth of this group (Table 7). The modified intrinsic rate of increase $\left(\mathrm{r}=\mathrm{b}_{\mathrm{o}}\right.$ $\mathrm{d}_{0}+\mathrm{I}_{\mathrm{o}}-\mathrm{E}_{0}$ ) for this population is 0.08 -i.e., beginning with 13 animals in 1972, the group should add 1.04 animals per year for a group size of 19 in 1978,20 in 1979 , etc. The actual group size for 1978 was 18 (Table 1). 


\section{DISCUSSION}

The present results confirm Carpenter's ('34) findings that howler females are sexually receptive for two or three days per cycle and that multiple matings occur before pregnancy. However, the ages for reproductive maturity reported here are much earlier than Carpenter's ('65) estimates of 48 to 60 months for females and 72 to 96 months for males. Napier and Napier ('67, citing Carpenter, '34) and Dukelow ( 70 , source unknown) listed 42 to 48 months for age at maturity. It is possible that young males joining other than their maternal group may be delayed in their sexual activity until they gain some social status, but not until they are six to eight years old.

The average estrus cycle length of 16 days for howlers is considerably less than the reported 23 to 26 days for Lagothrix (Napier and Napier, '67; Castellanos and McComb, '68; Dukelow, '70) and 24 to 27 days for Ateles (Napier and Napier, '67; Dukelow, '70), the other large bodied New World monkeys (5,000 to 6,500 g for woolly females and 5,820 g for spider females; Napier and Napier, '67). The howler cycle is more similar to that of the smaller New World primates, i.e., Cebus-15 to 20 days and Saimiri-10 to 14 days (Napier and Napier, '67; Castellanos and McComb, '68; Dukelow, '70). Size may be a factor, since female Costa Rican mantled howlers are not as large $(4,026$, $\mathrm{n}=24$ ) as either female spider or woolly monkeys. If there is a relationship between size and estrus cycle, then the larger Panamanian howlers should have longer estrus cycles than the smaller Costa Rican howlers, even though they are the same species. However, no information on cycles for the Panamanian howler is available.

Even though the exact time of ovulation in howlers is unknown, the behavior of the adult males may provide a clue. The alpha male copulated with receptive females only at the midpoint of the sexual skin swelling and was uninterested to the point of rejection of females at other times. This selectivity of the mating time by alpha male howlers may be similar to that found in baboons. Alpha male baboons only copulated with estrous females on or near the day of ovulation, thereby increasing their probability of impregnating the female (Hausfater, '75). Male howlers may be able to detect ovulation by testing the female's urine, since howlers have a well-developed and functional vomeronasal organ (Starck, '75).

There are large differences between my estimates of gestation (186 days) and that of 139 days reported by Dukelow ('70) and 140 days reported by Walker (75). The source of their estimates is not given. Their figures seem low given the 180 day and 168 to 182 day gestation reported for the smaller Cebus and Saimiri, respectively (Napier and Napier, '67; Castellanos and McComb, '68; Dukelow, '70). Napier and Napier ('67) and Dukelow ('70) both listed 139 days for Ateles'gestation. This duration also seems unlikely since another similar sized New World primate, Lagothrix, is reported to have a 225 day gestation (Napier and Napier, '67; Costellanos and McComb, '68; Dukelow, '70). If gestation length is related to size, then gestation for Ateles should fall in the 180 to 225 day range documented for Alouatta, Cebus, and Lagothrix.

Data on postpartum acyclicity and the length of interbirth intervals for other New World monkeys have not been published. Altmann et al. ('77) reported that baboons experienced a postpartum amenorrhea. The length of both the postpartum ammenorrhea and interbirth interval for baboons was shortened if the infant died during the 12 month ammenorrhea (Altmann et al., '77). For howlers, infant death during the first four months ends the postpartum acyclicity and drastically shortens the interbirth interval. Once the infant is four months old, it no longer influences the mother's future reproduction. However, the mother determines the ultimate fate of the infant.

An adult howler female's age, rank, and parity affected infant survival. No infants of $3 \frac{1}{2}$ to 41/2 year old primiparous, alpha females survived. Since primiparous females gave birth to their first infants about the same time they were obtaining the alpha position, the death of their infants may be linked to their behavior while achieving this position. These young females were involved in frequent dominance interactions before and after giving birth. The interactions could be directly detrimental to an infant because of the hazard of being knocked off and indirectly affect the infant because of the energy expended by the mother.

Jones ('78) has suggested that the major "payoff" of high status for mantled howlers involves reproductive success. That is not the case for the alpha position as shown here, but it was the "payoff" for those positions just below alpha (2nd, 3rd, 4th, 5th). The middle ranks had significantly higher reproductive success than either the highest or lowest ranks (Table 5). The alpha position may be important not for the immediate benefits gained while in that position (the costs of the alpha position exceeds 
the gains, i.e., loss of first infant, energy expenditure, etc.), but for the benefits gained while occupying the middle ranks when both reproductive and nutritional dividends are realized. And, the only way to enter the middle ranks has been from the top.

The timing of births also affected infant mortality. When births were spread out, mortality was high, but when births were clustered, mortality was low. If low infant mortality is desirable and is characteristic of clustered births, why not have clustered births every year? Is the low infant mortality associated with clustered births due to social or environmental effects? Jones (78) suggested that there is some advantage to the infant and/or mother if birth occurs during the dry season, the time of peak preferred food availability (Glander, '75). Yet the lack of a significant difference in the seasonal distribution of births reported here and by Jones (78) does not support this suggestion. Further, there is no significant seasonal difference in the nutrient content of howler food (Glander, '79). the problem for howlers is not total available nutrients, but rather the digestibility of those nutrients, since most of the plant material available to the howlers as food contains plant secondary compounds that interfere with digestibility or decrease quality (Glander, '79).

Thus, the plant chemicals affect the quality of the food and the howlers may respond by concentrating births in years when food quality is high and spreading births out in years of low food quality. The mechanism for what may be facultative birth spacing, something not reported previously for any primate, could be the inhibitory or triggering effect plant chemicals have on ovulation and conception. Similar occurrences have been documented in Microtus montanus (Berger et al., 77; Negus and Berger, '77), Lophortyx californicus (Starker, '76), and various domestic animals (Sadleir, '69). On the other hand, the mechanism could be information each female gathers about the reproductive condition of all other females during the greeting ceremony. Neither of these mechanisms are mutually exclusive and others are likely. Whatever the cause, the net result is differential infant mortality.

The unique dispersal pattern found in these howlers, where both males and females leave their natal group, has significant implications for kin selection arguments. The study group had grown from 13 to 18 animals (November, 1978), but recruitment has accounted for only one animal, the rest of the growth has been due to immigrants. The result of this kind of population growth is 1) that most of the group is composed of unrelated animals, or 2) that all neighboring groups are distantly related because of the high rate of gene exchange between groups. Given that animals leave their natal groups, it is very difficult to argue for traditional kin selection. The only way for kin selection to operate would be if animals who have successfully joined another group assisted their siblings, something that requires kin recognition and could occur only if the animals remained in their natal group more than two years. They would then be present when their mother produced her next offspring (23 month birth interval). All emigrants did remain in the study group more than two years.

Differences between the actual and predicted group size may be because a population grows exponentially only at population levels well below the carrying capacity $(\mathrm{K})$ of the environment and logistically as the population approaches " $K$ " (Wilson and Bossert, '71). The study site " $K$ " is unknown, but more animals left the group than entered (Table 7). If the group is at or near $K$, then it may be to an animal's advantage to leave; but why did five juveniles leave the group before it reached its present size? There was space available in the group as evinced by the fact that five animals joined the group. Also, why did Bonnie, Orange, and Able remain in their maternal group? All three of these animals rose to the alpha position for their sex. Were the animals that left the group unable to likewise succeed, and did they seek success in other groups? All of the five immigrants have at one time or another occupied the alpha position for their sex (both the present alpha male and female are immigrants).

Reproductive success (either classical or inclusive fitness) for howlers is very complex and is related to more than one environmental or social factor. The complexity and dynamic nature of these effects make simple explanations counterproductive. As indicated above, any hypotheses about kin selection and reproductive strategies in howlers must account for the impact that both environmental and social factors have on reproduction. My long-term study is continuing in an effort to uncover more of these factors.

\section{ACKNOWLEDGMENTS}

I thank M.H. Glander for her help during all stages of this work, Mr. and Mrs. Hagnauer for their permission to work on La Pacifica and their help in this continuing study, and $\mathrm{K}$. Brown and two unknown reviewers for helpful comments on the manuscript. I am grateful to 
M.A. Gottenborg, N.J. Scott, Jr., and M. Clarke for collecting and making available demographic data during times indicated in Table 1.

The study has been partially supported by NSF Dissertation Improvement Grant no. GS31733; Duke Biomedical Research Support Grants nos. 303-3789, and 303-3984; and Duke University Research Council Grant no. 4532417.

\section{LITERATURE CITED}

Altmann, S.A. (1959) Field observations on a howling monkey society. I. Mamm., 40:317-330.

Altmann, J., S.A. Altmann, G. Hausfater, and S.A. McCuskey (1977) Life history of yellow baboons: Physical development, reproductive parameters, and infant mortality. Primatology, 18:315-330.

Berger, P.J., E.H. Sanders, P.D. Gardner, and N.C. Negus (1977) Phenolic plant compounds functioning as reproductive inhibitors in Microtus montanus. Science, 195:575577.

Carpenter, C.R. (1934) A field study of the behavior and social relations of howling monkeys (Alouatta palliata). Comp. Psychol. Monogr., 10:1-168.

Carpenter, C.R. (1965) The howlers of Barro Colorado Island In: Primate Behavior. I. DeVore, ed. Holt, Rinehart, and Winston, New York, pp. 250-291.

Castellanos, H., and H.L. McCombs (1968) The reproductive cycles of the New World Monkey. Fertil. Steril., 19:213227.

Dukelow, W.R. (1970) Reproductive physiology of primates. Mich. Agr. Exp. Stat. J. Art. No. 5262.

Glander, K.E. (1975) Habitat and resource utilization: An ecological view of social organization in mantled howling monkeys. Dissertation, The University of Chicago, Chicago.

Glander, K.E. (1978) Howling monkey feeding behavior and plant secondary compounds: A study of strategies. In: The Ecology of Arboreal Folivores, G.G. Montgomery, ed. Smithsonian Institution Press, Washington, D.C., pp. $561-574$.

Glander, K.E. (1979) Feeding patterns in mantled howling monkeys. In: Mechanisms of Foraging. A. Kamil, ed. In Press.

Hausfater, G. (1975) Dominance and reproduction in baboons (Papio cynocephalus); A quantitative analysis. Contr. Prim., 7.

Jones, C.B. (1978) Aspects of reproductive behavior in the mantled howler monkey, Alouatta palliata Gray. Dissertation, Cornell University.

Leuthold, W. (1977) African Ungulates: A Comparative Review of Their Ethology and Behavioral Ecology. Springer-Verlag, New York.

Napier, J.R., and P.H. Napier (1967) A Handbook of Living Primates. Academic Press, London.

Negus, N.C., and P.J. Berger (1977) Experimental triggering of reproduction in a natural population of Microtus montanus. Science, 196:1230-1231.

Sadleir, R.M. (1969) The Ecology of Reproduction in Wild and Domestic Mammals. Methuer, London.

Scott, N.J., Jr., A.F. Scott, and L.A. Malmgren (1976) Capturing and marking howler monkeys for field behavioral studies. Primatology, 17:527-533.

Shoemaker, A.H. (1978) Observations on howler monkeys, A louatta caraya, in captivity. Zool. Gart. N.F., 48:225-234.

Starck, D. (1975) The development of the chondrocranium in primates. In: Phylogeny of the Primates. W.P. Luckett and F.S. Szalay, eds. Plenum Press, New York, pp. 127-155.

Starker, L.A. (1976) Phytoestrogens: Adverse effects on reproduction in California quail. Science, 191:98-100.

Walker, E.P. (1975) Mammals of the World. Johns Hopkins Press, Baltimore.

Wilson, E.O., and W.H. Bossert (1971) A Primer of Population Biology. Sinauer Associates, Stanford, Connecticut.

Wislocki, G.B. (1930) On a series of placental stages of a Platyrrhine monkey (Ateles geoffroyi) with some remarks upon age, sex, and breeding period in Platyrrhines. Cont. Embryol. Carn. Inst., 22:173-192. 